\title{
Contamination and Potential Ecological Risk Factors of Potentially Toxic Elements Present in the Soil of Shooting Range: Comparison with the Global Soils
}

\author{
Saba Shoukat ${ }^{1}$, Shahla Nazneen ${ }^{1}$, Sardar Khan ${ }^{1,2}$ \& Urooj Zafar ${ }^{1}$ \\ ${ }^{1}$ Department of Environmental Sciences, University of Peshawar, Pakistan \\ ${ }^{2}$ Urban Environment and Health, Institute of Urban Environment, Chinese Academy of Sciences, Xiamen, China \\ Correspondence: Saba Shoukat, Department of Environmental Sciences, University of Peshawar, 25120, \\ Pakistan. E-mail: sabashoukat35@yahoo.com
}

Received: November 29, 2019

doi:10.5539/ep.v9n1p37

\author{
Accepted: January 21, 2020 \\ Online Published: March 31, 2020 \\ URL: https://doi.org/10.5539/ep.v9n1p37
}

\begin{abstract}
This study was carried out to determine potentially toxic element (PTE) contamination and their potential ecological risk factors in shooting range soil. For this purpose soil samples were collected from different locations (left side, right side, shooting point, middle, and stop-butt) from the shooting range of Frontier Corps Training Centre (FCTC) present in Warsak, Peshawar. The soil samples were analyzed for $\mathrm{pH}$, electrical conductivity (EC) and potentially toxic elements including $\mathrm{Cd}, \mathrm{Cr}, \mathrm{Ni}, \mathrm{Pb}$, and $\mathrm{Zn}$. The strong acids digested extracts were analyzed using atomic absorption spectrophotometry to determine the concentrations of selected PTEs. The concentration of $\mathrm{Pb}$ was found to be maximum at stop-butt i.e. $2049 \mathrm{mg} / \mathrm{kg}$ and exceeded the United States Environmental Protection Agency (US-EPA) critical value of $400 \mathrm{mg} / \mathrm{kg}$, while its concentrations at left, right, shooting point and middle were $14.0 \mathrm{mg} / \mathrm{kg}, 18.8 \mathrm{mg} / \mathrm{kg}, 47.4 \mathrm{mg} / \mathrm{kg}$, and $18.2 \mathrm{mg} / \mathrm{kg}$, respectively and exceeded the background level of normal soils which is $10 \mathrm{mg} / \mathrm{kg}$ for Pb. This study revealed that the shooting range soil was highly contaminated with $\mathrm{Pb}$, and very high contamination factor and potential ecological risk for $\mathrm{Pb}$ was observed at stop-butt, very high contamination factor and potential ecological risk for $\mathrm{Cd}$, while moderate contamination factor for $\mathrm{Zn}$ was observed at all locations of the shooting range. In Pakistan, the environmental perspective of shooting range soils is overlooked and there is a need to take steps to avoid such contamination of soils with $\mathrm{Pb}$ and other PTEs that can enter into food chains and can also leach to contaminate the aquifer. Replacement of vegetation of shooting range with PTE tolerant species, addition of soil conditioners and uncontaminated soil would reduce the mobility of these contaminants into aerial portions of plants and protect the groundwater contamination.
\end{abstract}

Keywords: lead contamination, contamination factor, potentially toxic elements, ammunition pellets, shooting range

\section{Introduction}

The contamination of shooting range soils is an issue of global concern, because of the accumulation of potentially toxic elements (PTE) in soil which are derived from ammunition pellets (Dinake et al., 2019; Rodríguez-Seijo et al., 2017). The pellets used in ammunition are mainly composed of PTEs such as lead (Pb), zinc ( $\mathrm{Zn})$, antimony $(\mathrm{Sb})$, arsenic (As), copper $(\mathrm{Cu})$ and nickel (Ni) (Migliorini et al., 2004; Sanderson et al., 2014). When the spent ammunition pellets come into contact with water or soil, their weathering causes oxidation of metals to secondary forms such as oxides and carbonates, which are soluble hence serving as a source of PTE contamination into the soil. Many recent studies have shown that the soils of shooting ranges are highly contaminated with $\mathrm{Pb}$ due to abrasion of $\mathrm{Pb}$ bullets passing through the soil (Dinake et al., 2019; Islam and Park, 2017; Mariussen et al., 2017; Rodríguez-Seijo et al., 2017; Sehube et al., 2017).

The $\mathrm{Pb}$ contamination of shooting range soils has gained significant attention by the scientific community due to elevated concentrations of it present in the soils of shooting ranges and possible adverse effects to human health associated with exposure to $\mathrm{Pb}$ (Dinake et al., 2019; Sanderson et al., 2014; Sehube et al., 2017). The other components of bullets such as $\mathrm{Cu}$ (casing of the bullet), $\mathrm{Ni}$ and $\mathrm{Zn}$ (alloys with copper), $\mathrm{Sb}$ (hardening agent) and As (lead impurity) have also been identified in significant amounts in addition to Pb (Johnsen and Aaneby, 2019; 
Peddicord and LaKind, 2000). There is $97 \%$ of $\mathrm{Pb}$ in $\mathrm{Pb}$ - shots, while the Pb-bullets encompass $90 \%$ of metallic $\mathrm{Pb}$ (Fayiga and Saha, 2016). Despite of the presence of these metals in the Pb-based bullets in smaller amounts, they can accumulate at elevated levels in the soils (Hardison et al., 2004; Johnsen and Aaneby, 2019) and can contaminate the groundwater as well (Islam and Park, 2017; Sanderson et al., 2014). Pb is preferred metal to be used in manufacture of ammunition pellets (Dinake et al., 2019; Fayiga and Saha, 2016; Johnsen and Aaneby, 2019 ) because of its high density $\left(11.34 \mathrm{~g} / \mathrm{cm}^{3}\right)$, low melting point $\left(327.4^{\circ} \mathrm{C}\right)$, high malleability and high resistance to corrosion (Rodríguez-Seijo et al., 2017; Sehube et al., 2017).

$\mathrm{Pb}$ has harmful effects to animals, humans and all ecological resources (Islam and Park, 2017). In humans, deleterious health effects are more prominent in children. Even lower concentrations of $\mathrm{Pb}$ up to $10 \mu \mathrm{g} / \mathrm{dl}$, can instigate damage to the brain and nervous system, behavioral problems, hearing problems, slowed growth, headaches and impairment of vision in children(Sehube et al., 2017). In adults, complications during pregnancy, reproductive problems (like birth defects, low birth weight and decreased fertility), digestive problems, high blood pressure, neurological disorders, concentration and memory problems, kidney dysfunction and muscle/joint pain are associated with $\mathrm{Pb}$ exposure (Hardison et al., 2004; Sehube et al., 2017).

$\mathrm{Pb}$ contamination in the environment is of significant concern, because of having injurious effects on organ systems, particularly the neurological system, the kidneys and the blood (Dinake et al., 2019; Hardison et al., 2004; Tong et al., 2000). The issue of contamination of the shooting range soils requires special attention in order to continue the necessary operation of these ranges and ongoing use of the land without destroying the environment (Johnsen and Aaneby, 2019; Sanderson et al., 2014; Sorvari, 2011).

The purpose of this study was to determine PTE contamination particularly $\mathrm{Pb}$ and evaluate the contamination factor and ecological risk factor of PTEs in shooting range soil, Peshawar, Pakistan. According to authors' knowledge no one has conducted a systematic scientific study on the selected study area.

\section{Materials and Methods}

\subsection{The Study Area}

This study was carried out at Frontier Corps Training Centre (FCTC) Warsak, which lies on the north western boundary of Peshawar. Peshawar is the capital city of Khyber Pakhtunkhwa Province and lies between $33^{\circ} 44^{\prime}$ and $34^{\circ} 15^{\prime}$ north latitudes, $71^{\circ} 22^{\prime}$ and $71^{\circ} 42^{\prime}$ east longitude (Khan et al., 2016) (Fig.1). The FCTC shooting range was established in 1985, and was used by Swat scouts since 1996.

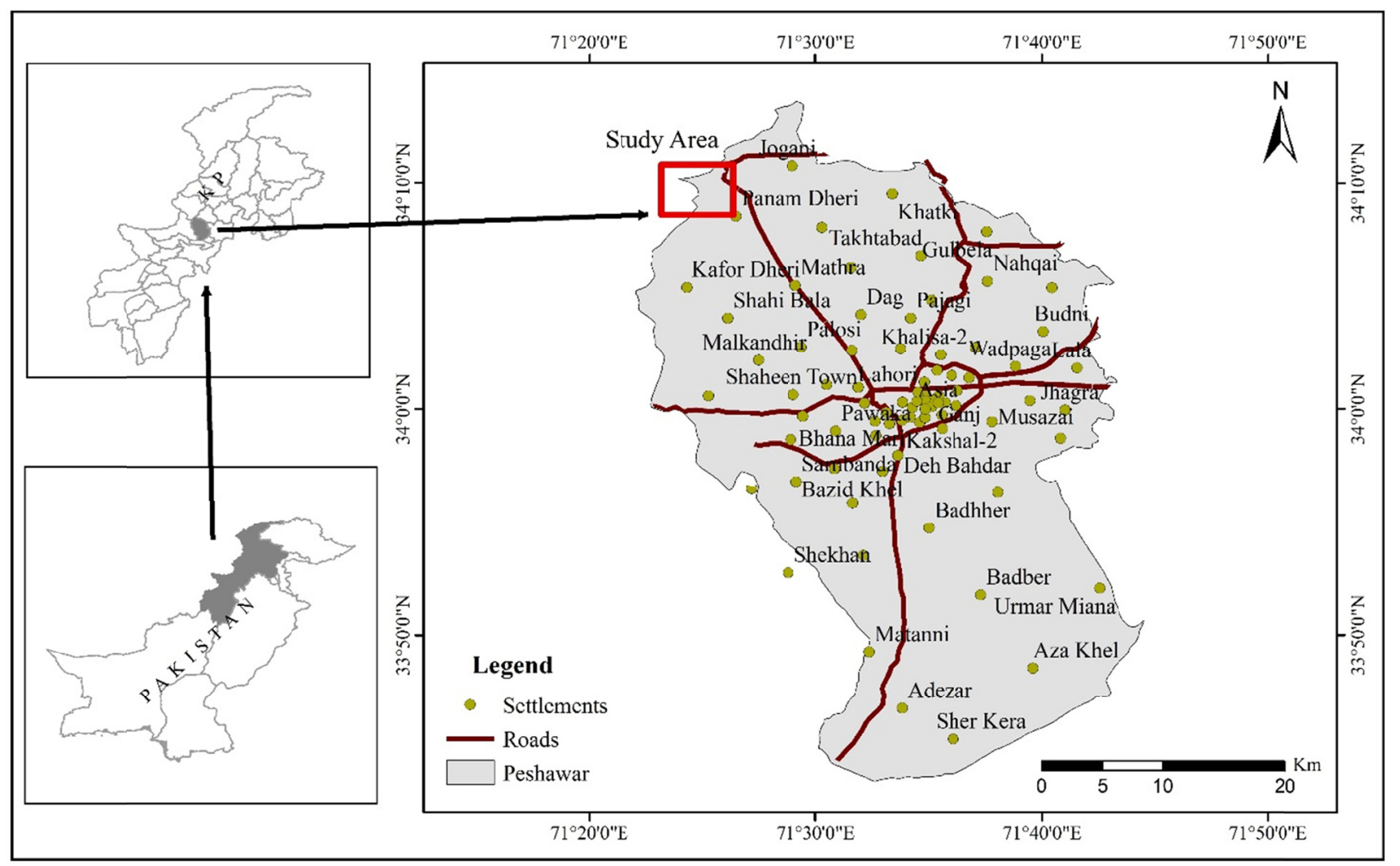

Figure 1. Location map of study area 


\subsection{Soil Sampling}

Five locations were selected in the shooting range i.e.; 1) shooting point, 2) middle, 3) stop-butt (also known as berm and back stop), 4) left, and 5) right. Three points were identified in each location on the basis of their distance from the middle point of the shooting range. The first point selected of each location was $200 \mathrm{~m}$ apart, second was $300 \mathrm{~m}$ apart and third was $400 \mathrm{~m}$ apart from the middle point. So three samples from left, right, stop-butt, and shooting point and one from the middle were taken. Total thirteen soil samples were collected at the depth of $0-15 \mathrm{~cm}$ with help of an auger and kept in polythene bags and properly marked.

The soil samples were air dried and then pulverized to 200-mesh size. The sieved and pulverized soil samples were kept in oven over night at $110^{\circ} \mathrm{C}$ to remove moisture. The samples were then cooled by placing in a desiccator and used for further analyses.

\subsection{Laboratory Analysis}

For determination of $\mathrm{pH}$ and electrical conductance (EC), soil was mixed with deionized water (1:5, weight: volume) in a glass beaker. The content was thoroughly mixed and allowed to stand for $30 \mathrm{~min}$ (Khan et al., 2016) The $\mathrm{pH}$ of soil solution was then recorded using $\mathrm{pH}$ meter (Melter Delta 320) after standardizing the instrument with standard buffer solutions. The EC of soil solution was then recorded using Conductometer (JENWAY 4060) after calibrating the instrument with freshly prepared standard of $\mathrm{KCl}$ solution.

For determination of PTEs, dried and pulverized soil samples $(1 \mathrm{~g})$ were taken in teflon beakers and $15 \mathrm{ml}$ of aqua regia $\left(\mathrm{HNO}_{3}: \mathrm{HCl}\right.$ at 1:3 ratio) was added and the samples were kept overnight following the method adopted by Khan et al. (2010). The subsequent morning, soil samples were steadily heated on hot plate in a fume hood until they were nearly dried up. The samples were slowly heated again till near to dryness after adding $5 \mathrm{ml}$ of $\mathrm{HClO}_{4}$. Then deionized water was added to the beakers and aliquot was filtered through watt-man filter paper No. 42 and diluted to $50 \mathrm{ml}$ with deionized water into volumetric flasks. The concentrations of selected PTEs such as $\mathrm{Pb}, \mathrm{Cd}, \mathrm{Zn}, \mathrm{Cr}$ and $\mathrm{Ni}$ in the extracts were determined using Atomic Absorption Spectrophotometer (Perkin Elmer 700) (Al-Khashman and Shawabkeh, 2006; Galal and Shehata, 2015; Rehman et al., 2017; Tüzen, 2003).

\subsection{Contamination Factor}

The contamination factor $\left(\mathrm{C}^{\mathrm{i}} \mathrm{f}\right)$ is defined as the ratio between elemental concentration between focus and the background areas. The following formula is used to determine contamination factor.

$$
\mathrm{C}_{\mathrm{i}}^{\mathrm{i}}=\mathrm{C}_{\mathrm{i}} / \mathrm{C}_{\mathrm{ri}}
$$

Where ' $\mathrm{C}_{\mathrm{i}}$ ' is the elemental concentration in focus area and ' $\mathrm{C}_{\mathrm{ri}}$ ' is the elemental concentration in the background area (Hakanson, 1980). The degrees of contamination factor and standard values are given in Table 2.

\subsection{Ecological Risk Factor}

The ecological risk factor $\left(\mathrm{Er}^{\mathrm{i}}\right)$ is used to express the potential ecological risk of a given contaminant, and it is determined through the following formula (Hakanson, 1980).

$$
E r^{i}=\operatorname{Tr}^{i} \times C^{i} f
$$

Where ' $\mathrm{Tr}^{\mathrm{i}}$ ' is the toxic-response factor for a given substance, and ' $\mathrm{C} \mathrm{f}$ ' ' is the contamination factor. The terminologies used to express the degrees of ecological risk factor are given in Table 2. 
Table 1. Soil basic properties, PTE concentrations and descriptive statistics of shooting range soil

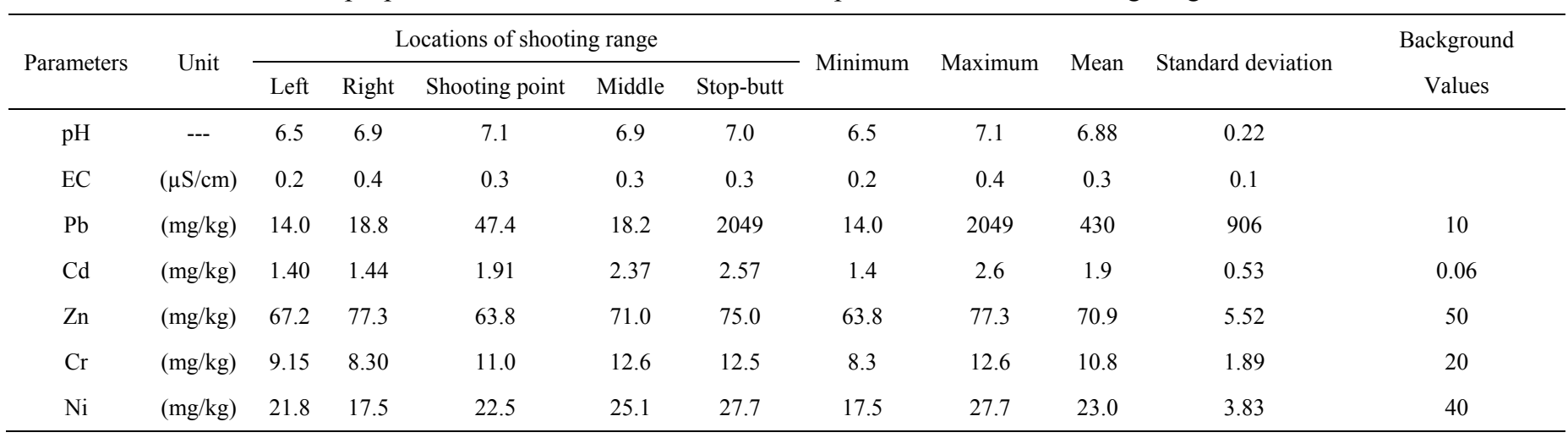

Table 2. Standard values of contamination factor and ecological risk factor

\begin{tabular}{llll}
\hline & Contamination factor & & Ecological risk factor \\
\hline Values & Degrees & Values & Degrees \\
\hline $\mathrm{C}^{\mathrm{i}} \mathrm{f}<1$ & Low contamination factor & $\operatorname{Er}^{\mathrm{i}}<40$ & low potential ecological risk \\
$1 \leq \mathrm{C}^{\mathrm{i}} \mathrm{f}<3$ & Moderate contamination factor & $40 \leq \mathrm{Er}^{\mathrm{i}}<80$ & moderate potential ecological risk \\
$3 \leq \mathrm{C}^{\mathrm{i}} \mathrm{f}<6$ & Considerable contamination factor & $80 \leq \mathrm{Er}^{\mathrm{i}}<160$ & considerable potential ecological risk \\
$\mathrm{C}^{\mathrm{i}} \mathrm{f} \geq 6$ & Very high contamination factor & $160 \leq \mathrm{Er}^{\mathrm{i}}<320$ & high potential ecological risk \\
\hline & & $\operatorname{Er}^{\mathrm{i}} \geq 320$ & very high ecological risk \\
\hline
\end{tabular}

\section{Results and Discussion}

\subsection{Soil Basic Properties}

Soil $\mathrm{pH}$ is the extremely significant factor that controls PTE speciation and their mobility in the soil solution (Han, 2007). The $\mathrm{pH}$ of soil samples ranged from 6.5 (slightly acidic) to 7.1 (near neutral) (Table 1). The EC of soil is an important parameter which measures the amounts of salts present in soil (USDA, 2014). No significant variation in EC values of different soil samples of shooting range was observed. The values of EC ranged from $0.2 \mu \mathrm{S} / \mathrm{cm}$ to $0.4 \mu \mathrm{S} / \mathrm{cm}$ (Table 1 ). The physical properties of soil influence the bioavailability and mobility of PTEs. The mobility of PTEs increases with decreasing $\mathrm{pH}$ and they become more bioavailable at low $\mathrm{pH}$ and vice versa (Khan et al., 2016).

\subsection{PTEs in Soil}

Table 1 summarizes the concentrations of selected PTEs in the soil samples collected from different locations of the shooting range, significant variation was observed in their concentrations. The concentrations of PTEs were compared with their respective background levels in the normal soils universally given by Bohn et al. (2002) and $\mathrm{Pb}$ concentration was also compared with the critical value of $\mathrm{Pb}$ given by United States Environmental Protection Agency (US-EPA). The PTE concentrations were found to be highest at stop-butt that could be linked with falling of ammunition pellets at stop-butt. Among the selected PTE concentrations ( $\mathrm{Pb}, \mathrm{Cd}, \mathrm{Zn}, \mathrm{Cr}$ and $\mathrm{Ni}$ ), $\mathrm{Pb}$ concentration was found highest at stop-butt, which was $2049 \mathrm{mg} / \mathrm{kg}$ far exceeding the USEPA critical value of $400 \mathrm{mg} / \mathrm{kg}$ (Sehube et al., 2017) and its concentrations at left, right, shooting points and middle were 14.0 $\mathrm{mg} / \mathrm{kg}, 18.8 \mathrm{mg} / \mathrm{kg}, 47.4 \mathrm{mg} / \mathrm{kg}$, and $18.2 \mathrm{mg} / \mathrm{kg}$, respectively, hence exceeded the background levels in normal soils $(10 \mathrm{mg} / \mathrm{kg})$. The higher $\mathrm{Pb}$ concentration at shooting point was possibly due to the discharge of $\mathrm{Pb}$ powder at the time of shooting of bullets, shots and projectiles. Whereas the possible reason of higher $\mathrm{Pb}$ concentration at the left, right and middle of shooting range was that some of the weathered $\mathrm{Pb}$ might have been mobilized and migrated to the other locations of shooting range.

These results were in agreement with those reported in previous studies like Sehube et al. (2017) because they have also observed higher concentration of $\mathrm{Pb}$ at soils of stop-butt and shooting line of different shooting ranges (maximum concentration of $\mathrm{Pb}$ was found at berm soil of Bephatshwa (TAB) shooting range (Botswana) i.e. $38,386 \mathrm{mg} / \mathrm{kg}$ ), due to the discharge of Pb powder. Fayiga and Saha (2016) have also reported the similar trend of $\mathrm{Pb}$ concentration in Florida shooting ranges, $\mathrm{Pb}$ concentration ranged from 10,068 mg/kg to 70,350 mg/kg in 
mid-berm (stop-butt) soils.

Table 3. Contamination factor and ecological risk factor of shooting range soil

\begin{tabular}{lccccccccccc}
\hline \multirow{2}{*}{ Locations } & \multicolumn{4}{c}{ Contamination factor $\left(\mathrm{C}^{\mathrm{i}} \mathrm{f}\right)$} & \multicolumn{7}{c}{ Ecological risk factor $\left(\mathrm{Er}^{\mathrm{i}}\right)$} \\
\cline { 2 - 12 } & $\mathrm{Pb}$ & $\mathrm{Cd}$ & $\mathrm{Zn}$ & $\mathrm{Ni}$ & $\mathrm{Cr}$ & $\mathrm{Pb}$ & $\mathrm{Cd}$ & $\mathrm{Zn}$ & $\mathrm{Ni}$ & $\mathrm{Cr}$ \\
\hline Left & 1.40 & 23.33 & 1.35 & 0.55 & 0.48 & 7.00 & 699.9 & 1.35 & 2.75 & 0.96 \\
Right & 1.88 & 24.00 & 1.55 & 0.44 & 0.42 & 9.40 & 720.0 & 1.55 & 2.20 & 0.84 \\
Shooting point & 4.74 & 31.83 & 1.28 & 0.56 & 0.55 & 23.70 & 954.9 & 1.28 & 2.80 & 1.10 \\
Middle & 1.82 & 39.67 & 1.42 & 0.63 & 0.63 & 9.10 & 1190.1 & 1.42 & 3.15 & 1.26 \\
Stop-butt & 204.95 & 42.83 & 1.50 & 0.69 & 0.63 & 1024.75 & 1284.9 & 1.50 & 3.45 & 1.26 \\
\hline \multicolumn{4}{c}{ Toxic Response (TR) of PTEs } & 5 & 30 & 1 & 5 & 2 \\
\hline
\end{tabular}

The pollution extent in the study area is determined through contamination factor. The values of contamination factor of $\mathrm{Pb}, \mathrm{Cd}, \mathrm{Zn}, \mathrm{Cr}$ and $\mathrm{Ni}$ at different locations of shooting range are given in Table 3.

At stop-butt, very high contamination factor $\left(\mathrm{C}^{\mathrm{i}} \mathrm{f} 204.95\right)$ for $\mathrm{Pb}$ was observed due to elevated $\mathrm{Pb}$ concentration found at this location and considerable $\mathrm{Pb}$ contamination was observed at shooting point with $\mathrm{C}^{\mathrm{i}} \mathrm{f} 4.74$.

The concentration of $\mathrm{Cd}$ at left, right, shooting point, middle and stop-butt of shooting range was $1.40 \mathrm{mg} / \mathrm{kg}$, $1.44 \mathrm{mg} / \mathrm{kg}, 1.91 \mathrm{mg} / \mathrm{kg}, 2.38 \mathrm{mg} / \mathrm{kg}$, and $2.57 \mathrm{mg} / \mathrm{kg}$, respectively, hence all the soil samples contain Cd higher than the background level i.e. $0.06 \mathrm{mg} / \mathrm{kg}$. Lee et al. (2002) also reported $\mathrm{Cd}$ concentration $(0.35 \mathrm{mg} / \mathrm{kg})$ exceeding the background level in the soil of Korean shooting range, and observed that the metal concentrations become higher when heavy continuous shooting is practiced in the range.

Very high contamination factor for $\mathrm{Cd}$ was observed at all locations of shooting range possibly due to low background level $(0.06 \mathrm{mg} / \mathrm{kg})$ of $\mathrm{Cd}$ in normal soils.

The concentration of $\mathrm{Zn}$ at left, right, shooting point, middle and stop-butt was $67.2 \mathrm{mg} / \mathrm{kg}, 77.3 \mathrm{mg} / \mathrm{kg}, 63.8$ $\mathrm{mg} / \mathrm{kg}, 71.0 \mathrm{mg} / \mathrm{kg}$, and $75.0 \mathrm{mg} / \mathrm{kg}$, respectively, hence exceeding background level (50 mg/kg). Sorvari (2011) reported similar kind of results in the shooting range of Finland, where he has observed $90 \mathrm{mg} / \mathrm{kg} \mathrm{Zn}$ concentration at shotgun range and $76 \mathrm{mg} / \mathrm{kg} \mathrm{Zn}$ concentration at rifle range. Lee et al. (2002) documented that in the soil of Korean shooting range the highest level of metal contaminant was found to be of $\mathrm{Zn}$ which was 90 $\mathrm{mg} / \mathrm{kg}$. The contamination factor values given in Table 3 indicate moderate $\mathrm{Zn}$ contamination at all five locations of the shooting range.

According to Bohn et al. (2002) the concentration of $\mathrm{Ni}$ and $\mathrm{Cr}$ in normal soil is $40 \mathrm{mg} / \mathrm{kg}$ and $20 \mathrm{mg} / \mathrm{kg}$, respectively. The $\mathrm{Ni}$ and $\mathrm{Cr}$ concentrations at left, right, shooting point, middle and stop-butt of shooting range were $12.5 \mathrm{mg} / \mathrm{kg}$ and $21.8 \mathrm{mg} / \mathrm{kg}, 17.5 \mathrm{mg} / \mathrm{kg}, 22.5 \mathrm{mg} / \mathrm{kg}, 25.1 \mathrm{mg} / \mathrm{kg}$ and $27.7 \mathrm{mg} / \mathrm{kg}$, respectively, and 9.15 $\mathrm{mg} / \mathrm{kg}, 8.30 \mathrm{mg} / \mathrm{kg}, 11.0 \mathrm{mg} / \mathrm{kg}, 12.6 \mathrm{mg} / \mathrm{kg}$ and $12.5 \mathrm{mg} / \mathrm{kg}$, respectively. The contamination factor values of $\mathrm{Ni}$ and $\mathrm{Cr}$ reveal their low contamination in soil of shooting range. The $\mathrm{Cr}$ concentration at all locations of shooting range was found within the background level of $\mathrm{Cr}$ in normal soils due to the fact that $\mathrm{Cr}$ is not found in the ammunition pellets as a constituent. The concentration of $\mathrm{Ni}$ was within the background concentration level found in normal soils probably due to the fact that this element is not present in the ammunition pellets in higher amounts. Sanderson et al. (2012) on the contrary, affirmed Ni concentration slightly higher than the background concentration level in the soil of four shooting ranges around Australia. The overall distribution of PTEs at different locations of shooting range is given in Fig. 2. 

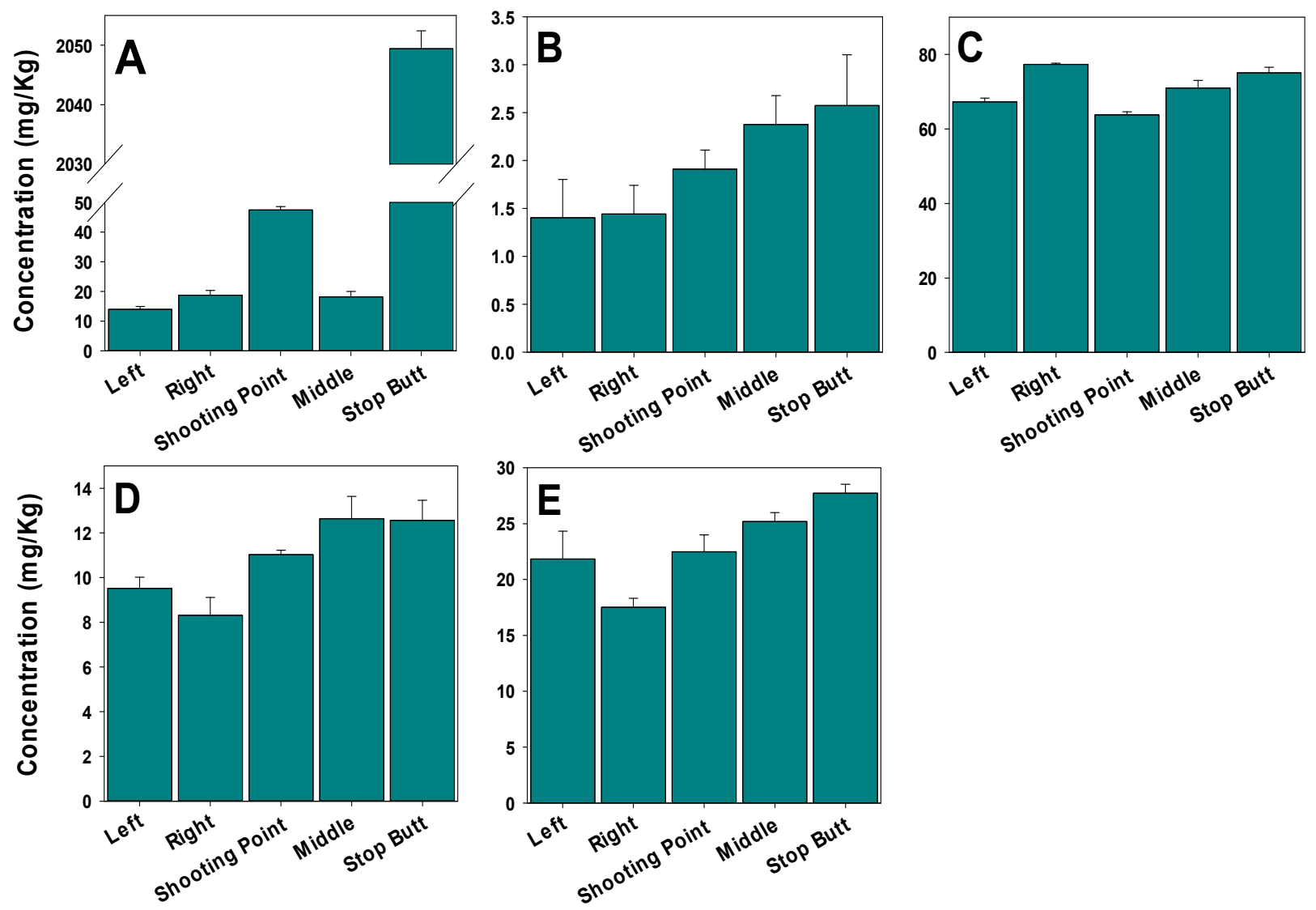

Figure 2. Concentrations (mg/kg) of PTEs at different locations of shooting range, whereas A, B, C, D, and E represent $\mathrm{Pb}, \mathrm{Cd}, \mathrm{Zn}, \mathrm{Cr}$ and $\mathrm{Ni}$, respectively. Error bars represent standard deviation

One way ANOVA using SPSS (version 21) was conducted to compare PTEs contamination at left, right, shooting point, middle and stop-butt. The PTEs $(\mathrm{Pb}, \mathrm{Cd}, \mathrm{Zn}, \mathrm{Cr}$ and $\mathrm{Ni}$ ) at stop-butt showed significant difference from left, right, middle and shooting point at $\mathrm{p}<0.05$ level. Similarly, significant difference was also recorded between all the locations for the PTE contamination at $\mathrm{p}<0.05$ level.

The values of potential ecological risk factor for $\mathrm{Pb}, \mathrm{Cd}, \mathrm{Zn}, \mathrm{Cr}$ and $\mathrm{Ni}$ at different locations of shooting range

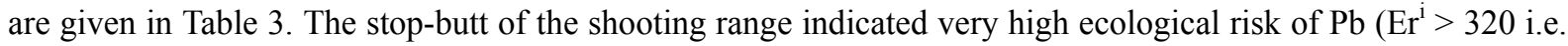
1024.75), whereas, at the other locations of shooting range, low potential ecological risk of $\mathrm{Pb}$ was observed. There was very high potential ecological risk of $\mathrm{Cd}$ in all locations of the shooting range due to the fact that $\mathrm{Cd}$ has a high toxic response (i.e. TR 30). The $\mathrm{Er}^{\mathrm{i}}$ values for $\mathrm{Zn}, \mathrm{Cr}$ and $\mathrm{Ni}$ were less than 40 at different locations of shooting range hence revealing low potential ecological risk of $\mathrm{Zn}, \mathrm{Cr}$ and $\mathrm{Ni}$ in the shooting range.

Warsak dam exists in the proximity of the study area due to which there is shallow water table upto $5 \mathrm{ft}$ in the study area, and about 48 tube wells are operational in the locality (Bilal and Sarwar, 2008). The Pb and $\mathrm{Cd}$ contamination in shooting range can be a serious hazard of ground water contamination in the study area. The contaminated ground water if used for irrigation can set off $\mathrm{Pb}$ contamination in plants also hence causing risk to biota and human health. The withdrawal from the aquifer in the vicinity of shooting range for drinking and domestic purposes may pose a serious risk to human health.

The ammunition pellets become disintegrated and pulverized upon impact with the soils of stop-butt, the disintegration causes change in the grain size distribution of shooting range soils and ultimately $\mathrm{Pb}$ contamination of environment is instigated as a result of weathering of bullet fragments (Fayiga and Saha, 2016; Johnsen and Aaneby, 2019). The primary issues associated with contaminated shooting ranges are mainly ecological risks. The adverse impacts on ecosystem include vegetation destruction, poisoning in several animal classes (including predatory birds, terrestrial birds, amphibians and small mammals) and major health risk to wildlife like mortality of birds due to accidental ingestion of Pb-bullets (Johnsen and Aaneby, 2019; Sorvari, 2011). 
There are many shooting ranges in Pakistan where shooting practices are carried out which suggests that $\mathrm{Pb}$ is being deposited at elevated rates on the soils of such areas consequently disrupting ecosystems and posing risk to human health. The remediation of soils of shooting ranges can be done by several methods based on phytoremediation, stabilization, physical separation and chemical treatment like extraction (Dinake et al., 2019; Sorvari et al., 2006).

\section{Conclusion}

The results of the study showed that the soil of Frontier Corps training centre

Warsak, Peshawar is highly contaminated with $\mathrm{Pb}$. The $\mathrm{Pb}$ concentration was found to be highest at the stop-butt because ammunition pellets fall at the stop-butt. The $\mathrm{Pb}$ concentration was also higher at the shooting point probably due to the discharge of $\mathrm{Pb}$ powder during shooting. There was very high contamination factor and potential ecological risk of $\mathrm{Pb}$ at stop-butt and very high contamination factor and potential ecological risk factor for $\mathrm{Cd}$ was also observed at all locations of the shooting range. The contaminated shooting range soils should be remediated with phytoremediation particularly phytoextraction, in this way the threat of ground water contamination can be eliminated. The shooting range vegetation should be replaced with the PTE tolerant plant species.

\section{Acknowledgements}

The authors greatly acknowledge the guidance and cooperation provided by

Major Jawad Ahmed Bukhari, Frontier Corps. We are thankful to FC for permitting us to collect soil samples from the shooting range.

\section{References}

Al-Khashman, O. A., \& Shawabkeh, R. A. (2006). Metals distribution in soils around the cement factory in southern Jordan. Environmental pollution, 140, 387-394. https://doi.org/10.1016/j.envpol.2005.08.023

Bilal, S. M., \& Sarwar, T. (2008). Effect of tube well drainage on water logging and salinity in Kafur Dheri Unit Peshawar. Sarhad Journal of Agriculture, 24, 49.

Bohn, H. L., Myer, R. A., \& O'Connor, G. A. (2002) Soil chemistry. John Wiley \& Sons.

Dinake, P., Kelebemang, R., Sehube, N. J. S., \& Journal, S. C. A. I. (2019). A comprehensive approach to speciation of lead and its contamination of firing range soils: A review. 28, pp. 431-459. https://doi.org/10.1080/15320383.2019.1597831

Fayiga, A., \& Saha, U. (2016). Soil pollution at outdoor shooting ranges: Health effects, bioavailability and best $\begin{array}{llll}\text { management } \quad \text { Environmental } & \text { Pollution, } & \text { 216, }\end{array}$ https://doi.org/10.1016/j.envpol.2016.05.062

Galal, T. M., \& Shehata, H. S. (2015). Bioaccumulation and translocation of heavy metals by Plantago major L. grown in contaminated soils under the effect of traffic pollution. Ecological Indicators, 48, 244-251. https://doi.org/10.1016/j.ecolind.2014.08.013

Hakanson, L. (1980). An ecological risk index for aquatic pollution control. A sedimentological approach. Water research, 14, 975-1001. https://doi.org/10.1016/0043-1354(80)90143-8

Han, F. X. (2007). Biogeochemistry of trace elements in arid environments. Springer Science \& Business Media.

Hardison, J., W, D., Ma, L.Q., Luongo, T., \& Harris, W.G. (2004). Lead contamination in shooting range soils from abrasion of lead bullets and subsequent weathering. Science of the total environment, 328, 175-183. https://doi.org/10.1016/j.scitotenv.2003.12.013

Islam, M. N., \& Park, J.-H. (2017). Immobilization and reduction of bioavailability of lead in shooting range soil through hydrothermal treatment. Journal of environmental management, 191, 172-178. https://doi.org/10.1016/j.jenvman.2017.01.017

Johnsen, I. V., \& Aaneby, J. (2019). Soil intake in ruminants grazing on heavy-metal contaminated shooting ranges. Science of the Total Environment, 687, 41-49. https://doi.org/10.1016/j.scitotenv.2019.06.086

Khan, S., Munir, S., Sajjad, M., \& Li, G. (2016). Urban park soil contamination by potentially harmful elements and human health risk in Peshawar City, Khyber Pakhtunkhwa, Pakistan. Journal of Geochemical Exploration, 165, 102-110. https://doi.org/10.1016/j.gexplo.2016.03.007 
Khan, S., Rehman, S., Khan, A. Z., Khan, M. A., \& Shah, M. T. (2010). Soil and vegetables enrichment with heavy metals from geological sources in Gilgit, northern Pakistan. Ecotoxicology and Environmental Safety, 73, 1820-1827. https://doi.org/10.1016/j.ecoenv.2010.08.016

Lee, I.-S., Kim, O. K., Chang, Y.-Y., Bae, B., Kim, H. H., \& Baek, K. H. (2002). Heavy metal concentrations and enzyme activities in soil from a contaminated Korean shooting range. Journal of Bioscience and Bioengineering, 94, 406-411. https://doi.org/10.1016/S1389-1723(02)80217-1

Mariussen, E., Heier, L. S., Teien, H. C., Pettersen, M. N., Holth, T. F., Salbu, B., \& Rosseland, B. O. (2017). Accumulation of lead $(\mathrm{Pb})$ in brown trout (Salmo trutta) from a lake downstream a former shooting range. Ecotoxicology and Environmental Safety, 135, 327-336. https://doi.org/10.1016/j.ecoenv.2016.10.008

Migliorini, M., Pigino, G., Bianchi, N., Bernini, F., \& Leonzio, C. (2004). The effects of heavy metal contamination on the soil arthropod community of a shooting range. Environmental Pollution, 129, 331-340. https://doi.org/10.1016/j.envpol.2003.09.025

Peddicord, R. K., \& LaKind, J. S. (2000). Ecological and human health risks at an outdoor firing range. Environmental Toxicology and Chemistry, 19, 2602-2613. https://doi.org/10.1002/etc.5620191029

Rehman, Z. U., Khan, S., Brusseau, M. L., \& Shah, M. T. (2017). Lead and cadmium contamination and exposure risk assessment via consumption of vegetables grown in agricultural soils of five-selected regions of Pakistan. Chemosphere, 168, 1589-1596. https://doi.org/10.1016/j.chemosphere.2016.11.152

Rodríguez-Seijo, A., Cachada, A., Gavina, A., Duarte, A., Vega, F., Andrade, M., \& Pereira, R. (2017). Lead and PAHs contamination of an old shooting range: A case study with a holistic approach. Science of The Total Environment, 575, 367-377. https://doi.org/10.1016/j.scitotenv.2016.10.018

Sanderson, P., Naidu, R., \& Bolan, N. (2014). Ecotoxicity of chemically stabilised metal (loid) s in shooting range soils. Ecotoxicology and environmental safety, 100, 201-208. https://doi.org/10.1016/j.scitotenv.2016.10.018

Sanderson, P., Naidu, R., Bolan, N., Bowman, M., \& Mclure, S. (2012). Effect of soil type on distribution and bioaccessibility of metal contaminants in shooting range soils. Science of the total environment, 438, 452-462. https://doi.org/10.1016/j.scitotenv.2012.08.014

Sehube, N., Kelebemang, R., Totolo, O., Laetsang, M., Kamwi, O., \& Dinake, P. (2017). Lead pollution of shooting range soils. South African Journal of Chemistry, 70, 21-28. https://doi.org/10.17159/0379-4350/2017/v70a4

Sorvari, J. (2011). Shooting ranges: environmental contamination. Encyclopedia of environmental health, 5, 41-50. https://doi.org/10.1016/B978-0-444-52272-6.00429-3

Sorvari, J., Antikainen, R., \& Pyy, O. (2006). Environmental contamination at Finnish shooting ranges-the scope of the problem and management options. Science of the Total Environment, 366, 21-31. https://doi.org/10.1016/j.scitotenv.2005.12.019

Tong, S., Schirnding, Y. E. V., \& Prapamontol, T. (2000). Environmental lead exposure: a public health problem of global dimensions. Bulletin of the World Health Organization, 78, 1068-1077.

Tüzen, M. (2003). Determination of heavy metals in soil, mushroom and plant samples by atomic absorption spectrometry. Microchemical Journal, 74, 289-297. https://doi.org/10.1016/S0026-265X(03)00035-3

USDA. (2014). Assessing soil health and soil fertility. NRCS, Islamabad, Pakistan.

\section{Copyrights}

Copyright for this article is retained by the author(s), with first publication rights granted to the journal.

This is an open-access article distributed under the terms and conditions of the Creative Commons Attribution license (http://creativecommons.org/licenses/by/4.0/). 